\title{
Trace-metal content of the Cerro Quema Au-Cu deposit (Azuero Peninsula, Panama): Implications for exploration
}

\author{
Isaac Corral, Mercè Corbella, David Gómez-Gras, Albert Griera
}

\section{Isaac Corral}

I.Corral.Geo@gmail.com

EGRU (Economic Geology Research Centre), College of Science and Engineering, James Cook University, Townsville, QLD 4811, Australia.

Departament de Geologia, Universitat Autònoma de Barcelona, 08193, Barcelona, Spain.

\section{Mercè Corbella David Gómez-Gras Albert Griera}

Departament de Geologia, Universitat Autònoma de Barcelona, 08193, Barcelona, Spain.

BOL. SOC. GEOL. MEX. 2018

VOL. 70 NO. 2

P. $549-565$

http://dx.doi.org/10.18268/BSGM2018v70n2a14

\section{ABSTRACT}

Cerro Quema (Azuero Peninsula, Panama) is a high-sulfidation epithermal $\mathrm{Au}-\mathrm{Cu}$ deposit hosted by a dacite dome complex of the Río Quema Formation (late Campanian to Maastrichtian). High-sulfidation mineralization at Cerro Quema occurs within a lithocap of vuggy quartz and advanced argillic alteration, and comprises a first stage of disseminations and microveinlets of pyrite, chalcopyrite, enargite, tennantite, and minor sphalerite. This stage is crosscut by younger veins that contain quartz, barite, pyrite, chalcopyrite, sphalerite, and galena. Later weathering and oxidation processes have produced two distinct mineralized zones at Cerro Quema: (1) Sulfide ore zone-a deeper zone of hypogene alteration and sulfide mineralization with some secondary enrichment but unaffected by oxidation, and (2) Oxide ore zone-a thick iron oxide-rich zone that overprints the hypogene alteration/ mineralization in the upper $\sim 150 \mathrm{~m}$ of the deposit. To characterize the concentrations and distribution of metals in the two ore zones, and to develop geochemical tools for exploration, we analyzed 34 samples of both oxide ( $\mathrm{n}$ = 23) and sulfide ore $(\mathrm{n}=11)$ for $\mathrm{Au}, \mathrm{Ag}, \mathrm{Cd}$, $\mathrm{Cu}, \mathrm{Mn}, \mathrm{Mo}, \mathrm{Ni}, \mathrm{Pb}, \mathrm{Zn}, \mathrm{S}, \mathrm{As}, \mathrm{Ba}, \mathrm{Hg}$, Sb, and $\mathrm{W}$ by INAA and ICP-MS. The results show that the oxide ore has the highest concentration of $\mathrm{Au}(2.4 \mathrm{~g} / \mathrm{t}), \mathrm{Ag}(2.0 \mathrm{~g} / \mathrm{t}), \mathrm{Pb}(432 \mathrm{ppm})$, and $\mathrm{Sb}(317 \mathrm{ppm})$, whereas the sulfide ore has the highest concentration of $\mathrm{Cu}(>1 \%), \mathrm{Zn}$ (403 ppm), As (2.74\%), and Cd (15.2 ppm). The enrichment factor calculation (oxide/ sulfide ore) indicate that $\mathrm{Au}, \mathrm{Ag}, \mathrm{Pb}$, and $\mathrm{Sb}$ are concentrated in the oxide zone whereas $\mathrm{Cu}, \mathrm{Zn}, \mathrm{Ba}, \mathrm{Ni}, \mathrm{As}$, and $\mathrm{S}$ are concentrated in the sulfide zone. Exploration for Au should target the oxide ore zone, in areas where the Ba concentration is also high. Exploration for $\mathrm{Cu}$ should target the sulfide ore zone, below the oxidation boundary, where primary and secondary $\mathrm{Cu}$ sulfides coexist.

Keywords: Exploration, Epithermal, Gerro Quema, Gold-Gopper, Panama.

\section{RESUMEN}

Cerro Quema (Península de Azuero, Panamá) es un depósito epitermal de alta sulfuración de $\mathrm{Au}$-Cu hospedado en el complejo de domos dacíticos de la Formación Río Quema (Campaniense Superior - Maastrichtiense). La mineralización de tipo epitermal de alta sulfuración en Cerro Quema ocurre en un lithocap de cuarzo vuggy y alteración argílica avanzada, y está compuesta por un primer estadio de diseminaciones y microvetas de pirita, calcopirita, enargita, tennantita y en menor cantidad esfalerita. Este tipo de mineralización está cortada por un segundo estadio más joven de vetillas que contienen cuarzo, barita, pirita, calcopirita, esfalerita y galena. Posteriormente, los procesos de meteorización y oxidación produjeron dos zonas mineralizadas distintas en Cerro Quema; (1) Zona de sulfuros: zona más profunda del yacimiento, caracterizada por alteración/mineralización hipogénica, con menor grado de enriquecimiento secundario pero libre de óxidos, y (2) Zona de óxidos: zona superficial caracterizada por óxidos de hierro, desarrollada hasta $\sim 150 \mathrm{~m}$ de profundidad y sobreimpuesta a la alteración/mineralización hipogénica. Para caracterizar la concentración y distribución de metales en las dos zonas mineralizadas, como también para desarrollar herramientas de exploración geoquímica, hemos analizado la concentración de $\mathrm{Au}, \mathrm{Ag}, \mathrm{Cd}, \mathrm{Cu}, \mathrm{Mn}, \mathrm{Mo}, \mathrm{Ni}, \mathrm{Pb}, \mathrm{Zn}$, $\mathrm{S}, \mathrm{As}, \mathrm{Ba}, \mathrm{Hg}$, Sb, y W mediante INAA e ICP-MS en 34 muestras de ambas zonas mineralizadas, óxidos $(n=23)$ y sulfuros $(n=11)$. Los resultados muestran que la zona de óxidos tiene la concentración más elevada de $\mathrm{Au}$ (2.4 g/t), Ag (2.0 g/t), Pb (432 ppm), y Sb (317 ppm), mientras que la zona de sulfuros tiene la concentración más elevada de Cu (> 1\%), Zn (403 ppm), As (2.74\%), y Cd (15.2 ppm). El cálculo del factor de enriquecimiento (óxidos/sulfuros) indica que el $\mathrm{Au}, \mathrm{Ag}, \mathrm{Pb}$ y $\mathrm{Sb}$ se concentran en la zona de óxidos, mientras el $\mathrm{Cu}, \mathrm{Zn}, \mathrm{Ba}, \mathrm{Ni}$, As y $\mathrm{S}$ se concentran en la zona de sulfuros. La exploración de Au en este tipo de depósitos debe centrarse en la zona de óxidos, donde la concentración de Ba es también elevada. Por el contrario, la exploración de Cu en este tipo de depósitos debe centrarse en la zona de sulfuros, por debajo de la zona de oxidación, donde coexisten tanto sulfuros primarios como sulfuros secundarios.

Palabras clave: Exploración, Epitermal, Cerro Quema, Oro-Cobre, Panamá. 


\section{Introduction}

The Cerro Quema deposit located in the Azuero Peninsula (SW Panama) consists of several mineralized bodies. From west to east, these include La Pava, Cerro Quemita, Mesita, and Cerro Quema (Figure 1). Global measured, indicated, and inferred resources for the Cerro Quema deposit (four orebodies) include a total oxide resource of $24.60 \mathrm{Mt} @ 0.71 \mathrm{~g} / \mathrm{t} \mathrm{Au}$ and 0.04\% Cu, and a total sulfide resource of $11.38 \mathrm{Mt} @ 0.41 \mathrm{~g} / \mathrm{t} \mathrm{Au}$ and $0.31 \% \mathrm{Cu}$ (Sutcliffe et al., 2014). Ore grade and tonnage are variable through the different orebodies. This variability can be summarized as follows (Sutcliffe et al., 2014):

- La Pava measured, indicated, and inferred oxide resources: 18.28 Mt @0.66 g/t Au and $0.04 \% \mathrm{Cu}$. Measured, indicated, and inferred sulfide resources: $8.54 \mathrm{Mt} @ 0.39 \mathrm{~g} / \mathrm{t}$ Au and 0.36\% $\mathrm{Cu}$.

- Cerro Quemita + Cerro Quema + Mesita indicated and inferred oxide resources: $6.32 \mathrm{Mt}$ (a) $0.83 \mathrm{~g} / \mathrm{t} \mathrm{Au}$ and $0.03 \% \mathrm{Cu}$. Indicated and inferred sulfide resources: 2.84 Mt @ $0.47 \mathrm{~g} / \mathrm{t} \mathrm{Au}$ and $0.15 \% \mathrm{Cu}$.

Additional orebodies have been discovered to the east of Cerro Quema; however, their resources have not yet been assessed.

Although several studies have been performed on the geology of the deposit (Leach, 1992; Horlacher and Lehmann, 1993; Torrey and Keenan, 1994; Nelson, 1995; Corral et al., 2011), on its origin and evolution (Corral et al., 2016, 2017), and on the metallogenic potential of the Azuero Peninsula (Del Giudice and Recchi, 1969; Ferenčić, 1970; Kesler et al., 1977; Corral et al., 2016), there is still a gap in the knowledge of the trace metal composition of the Cerro Quema Au-Cu ore.

Lithocaps associated with high-sulfidation epithermal deposits can have large extensions of advanced argillic altered rocks $\left(>20 \mathrm{~km}^{2}\right)$. However, typically only a small portion of the lithocap is mineralized, and due to the lack of directional indicators, exploration in this environment can be difficult (Sillitoe, 1995; Corbett and Leach 1998;
Chang et al., 2011). The study of the concentrations and distribution of metals in ore deposits is an essential tool for greenfield and brownfield exploration. Many deposits may contain anomalous concentrations of metals other than those of primary economic interest (Kesler et al., 2003), and these metals can be used as prospective guides to high-grade mineralization. High-sulfidation epithermal deposits commonly contain economically important amounts of $\mathrm{Au}, \mathrm{Ag}$, and $\mathrm{Cu}$, as well as significant tenors of $\mathrm{As}, \mathrm{Sb}, \mathrm{Hg}, \mathrm{Sn}, \mathrm{Te}$, and $\mathrm{Bi}$ (e.g, Arribas, 1995; Arribas et al., 1995; Kesler et al., 2005). Although these elements are probably of magmatic origin (e.g., Heinrich et al., 2004), they may vary significantly in relative abundance within individual deposits. This suggests that the fluid composition changed throughout the lifespan of the magmatic-hydrothermal system (Deditius et al., 2009) possibly due to water-rock interaction, or cooling/mixing processes.

Geochemical data of trace elements in high-sulfidation epithermal ores has been reported for decades (e.g., Rodalquilar: Hernandez et al., 1989; Nansatsu: Hedenquist et al., 1994; Pueblo Viejo: Kesler et al., 2003, Sillitoe et al., 2006; Cerro de Pasco: Baumgartner et al., 2008; Martabe: Sutopo, 2013). Here we present a case study of the metal content of the Cerro Quema Au-Cu deposit. We use whole-rock geochemical analysis of ore samples to better understand the deposit enrichment, its metal distribution and association of metals and minerals. Furthermore, we present useful criteria for exploration of high-sulfidation $\mathrm{Au}-\mathrm{Cu}$ deposits.

\section{Geologic setting}

\subsection{REGIONAL GEOLOGY}

The Cerro Quema high-sulfidation epithermal $\mathrm{Au}-\mathrm{Cu}$ deposit covers an area of $\sim 20 \mathrm{~km}^{2}$ in the center of the Azuero Peninsula (Figure 1). The mineralization is hosted in the dacite dome complex of the Río Quema Formation (late Campanian to Maastrichtian; Corral et al., 2013, 2016). 


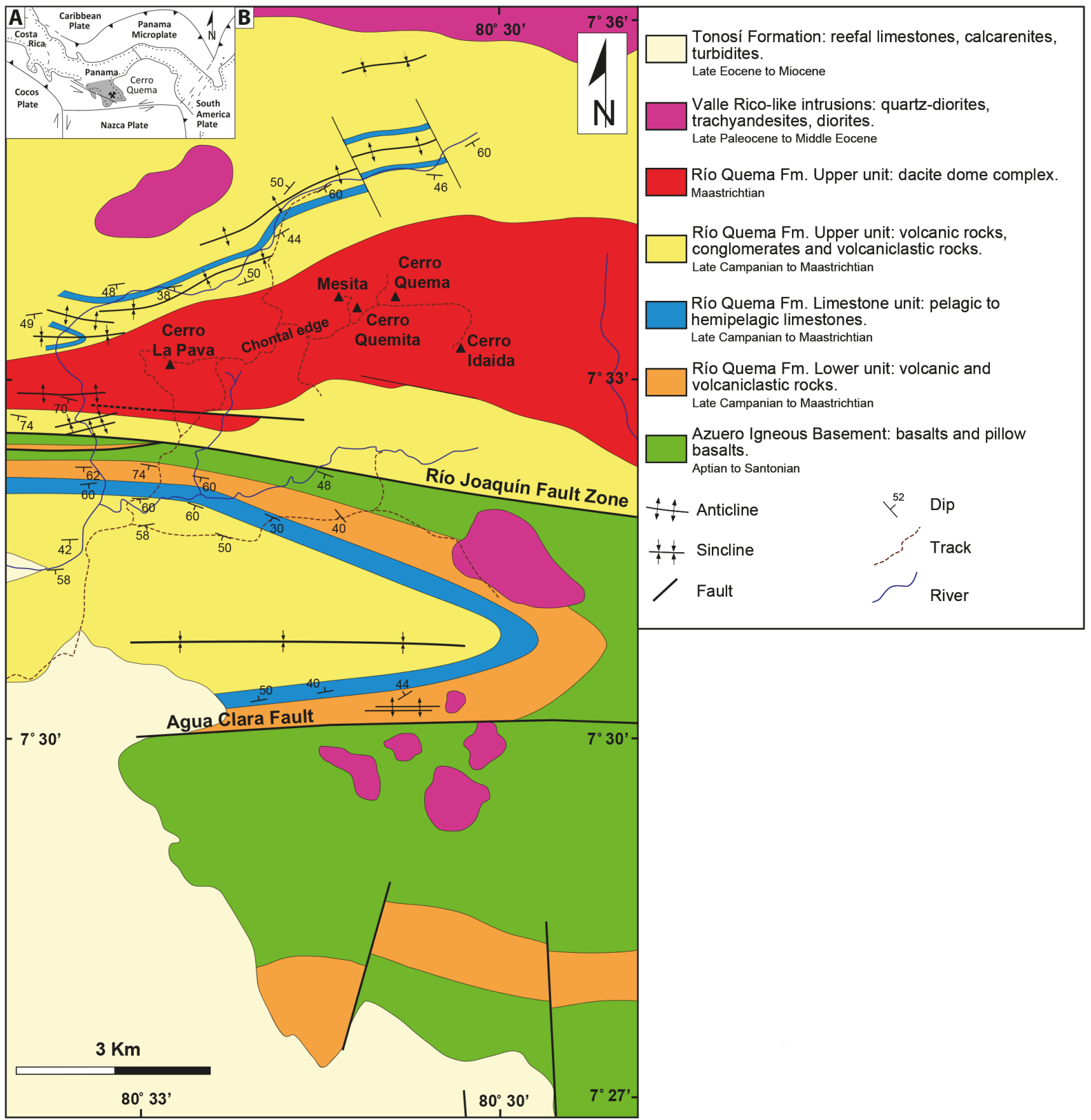

Figure 1 (A) Plate tectonic setting of south Central America (Azuero Peninsula is shaded). (B) Simplified geologic map of central Azuero Peninsula and location of the Cerro Quema Au-Cu deposit (after Corral et al., 2013, 2016).

As described in Buchs et al. (2010, 2011) and Corral et al. (2011, 2013), the Azuero Arc Group (late Cretaceous to Eocene) overlies the Azuero Igneous Basement (Conacian to Santonian) and is discordantly overlapped by the Tonosí Formation (Eo- cene to Miocene). The Río Quema Formation is a volcanosedimentary sequence that represents the earliest calc-alkaline volcanism of the Azuero Arc Group. In the Cerro Quema area, this sequence is bounded to the north by the Valle Rico batholith, 
a series of Eocene (55-49 Ma; Del Giudice and Recchi, 1969; Kesler et al., 1977; Lissinna, 2005; Montes et al., 2012; Corral et al., 2016) diorite and quartz diorite intrusions with calc-alkaline affinity. The Late Cretaceous Azuero Igneous Basement (Aptian to Santonian; Kolarsky et al., 1995; Kerr et al., 1997; Hoernle et al., 2002; Lissinna, 2005; Buchs et al., 2010) comprises tholeiitic basalts and pillow basalts with oceanic plateau affinity that bounds the Río Quema Formation to the south (Figure 1). A complete geochemical characterization of the igneous rocks of the Azuero Peninsula is provided by Hoernle et al. (2002, 2004), Lissinna, (2005), Wörner et al. (2009), Buchs et al. (2010, 2011), Corral et al. (2010, 2011), and Wegner et al. (2011). The main tectonic structures in the district include the east-trending Agua Clara and Río Joaquín Fault zones. An extensive network of minor northwest- to northeast-trending subvertical faults with normal dip-slip and minor strike-slip components are observed. In addition, mesoscale southwest-plunging open folds with moderately dipping limbs are observed. Overall, the structures suggest dextral transpression with dominant reverse dipslip motion during late Campanian to middle Eocene time (Corral et al., 2013).

\subsection{GEOLOGY OF THE GERRO QUEMA DEPOSIT}

\subsubsection{EXPLORATION HISTORY}

In 1965, a regional study of the geology and metallogeny of Panama financed by the United Nations Development Program (UNDP) was undertaken to evaluate Panama's mineral resources potential. Results in the Azuero Peninsula (e.g., Del Giudice and Recchi, 1969) revealed areas with significant copper and gold anomalies that were related to porphyry copper and epithermal deposits. These findings were later confirmed by Ferenčić (1970, 1971) and Kesler et al. (1977). In 1986-1988, the Compañía de Exploración Mineral S.A. (CEMSA) further investigated the area and eventually discovered Cerro Quema, which was considered a potentially mineable target. From 1990 to 1994, Cyprus Amax Minerals carried out several exploration programs including both soil geochemistry and drilling campaigns (4622 $\mathrm{m}$ of core drilling and 17579 m of RC drilling). In 1996, Campbell Resources Inc. carried out an infill drilling program to further define the resources (1750 m of core drilling), and completed a Project Feasibility Study. By 2007, Bellhaven Copper \& Gold Inc. acquired the project, and completed a feasibility study for the project together with metallurgical tests. Pershimco Resources Inc. acquired the project in 2010 and drilled $16939 \mathrm{~m}$ of core drilling in 79 holes and $32728 \mathrm{~m}$ of RG drilling in 330 holes. Additionally, the company completed a lithological and structural mapping of the area, and performed channel sampling and geochemical sampling. Several geophysical surveys have been carried out including an Induced Polarization (IP) survey as well as airborne radiometric, magnetic, and VTEM surveys (e.g., Kwan et al., 2016). In 2016 Pershimco Resources Inc. merged with Orla Mining Ltd. to continue the exploration and development of the Cerro Quema project under the name Orla Mining Ltd.

\subsubsection{HYDROTHERMAL ALTERATION}

Hydrothermal alteration at Cerro Quema follows an eastward trend that is parallel to secondary faults related to the Río Joaquín Fault Zone. It is defined by several concentric alteration halos that are mainly restricted to dacite domes of the Río Quema Formation, which have higher porosity and permeability than other rock types of the volcano-sedimentary sequence (Corral et al., 2017).

According to Corral et al. (2011, 2016), four distinct alteration zones can be identified at Cerro Quema: several vuggy quartz centers (up to $\sim 600$ $m$ in length) and local advanced argillic alteration zones (up to $\sim 250 \mathrm{~m}$ in length) are observed within the central core of the deposit, enclosed by an argillic alteration zone (up to $\sim 1900 \mathrm{~m}$ in length). The propylitic alteration forms an outermost halo surrounding the argillic alteration zone. Vuggy quartz alteration consists of a groundmass of microcrystalline anhedral quartz grains with disseminated pyrite, chalcopyrite, enargite, tennantite, barite, minor rutile, and trace sphalerite. In this alteration, the morphology of the vugs varies from 

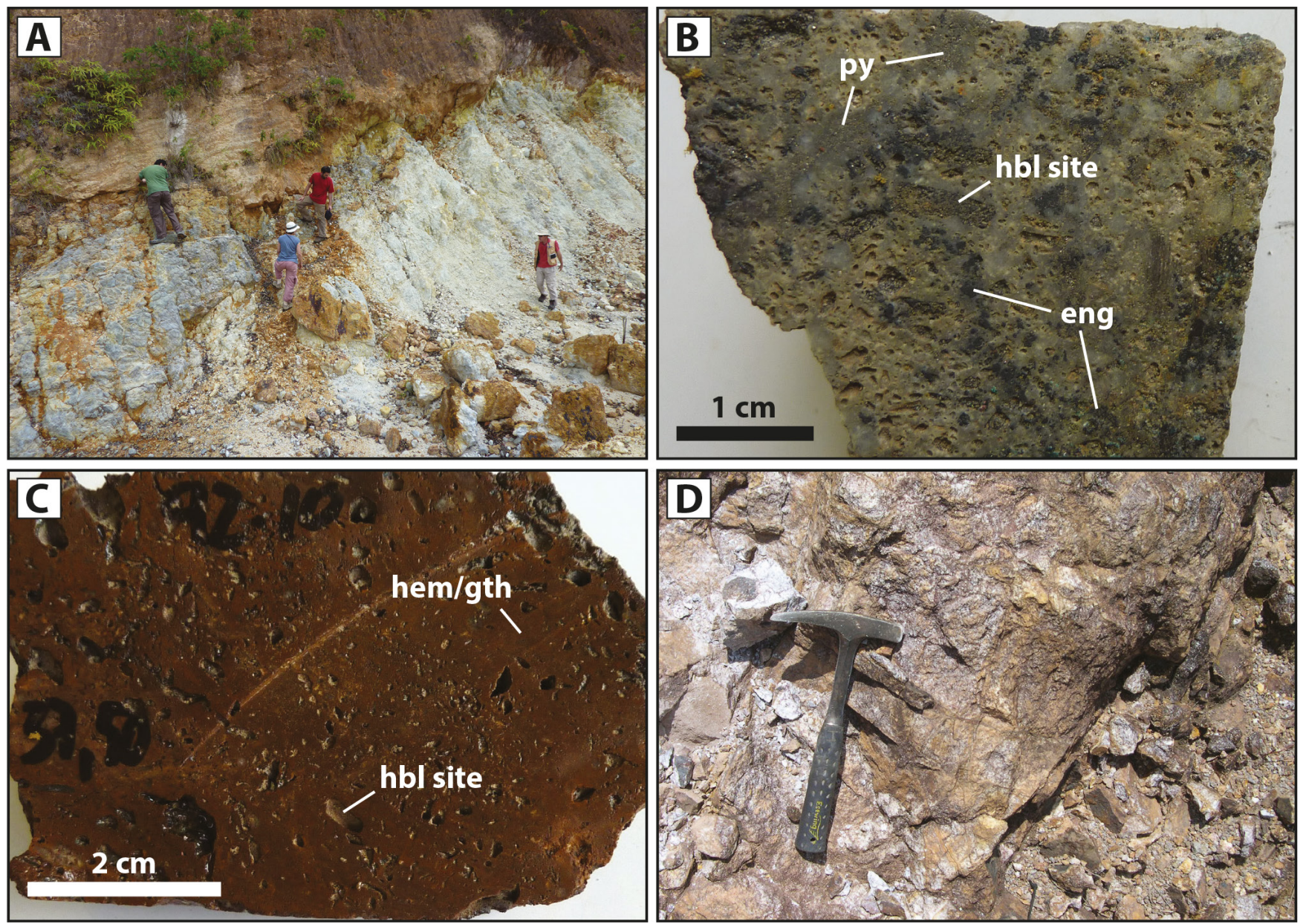

Figure 2 Examples of ore zones at Cerro Quema. (A) Oxidation boundary developed on the advanced argillic alteration zone. (B) Sulfide ore in drill hole (sample 9343-77; $0.31 \mathrm{~g} / \mathrm{t} \mathrm{Au},>1.0 \% \mathrm{Cu}$ ). (C) Oxide ore in drill hole (sample 9210-37.50; $2.07 \mathrm{~g} / \mathrm{t} \mathrm{Au,} \mathrm{0.11 \%} \mathrm{Cu).} \mathrm{(D)}$

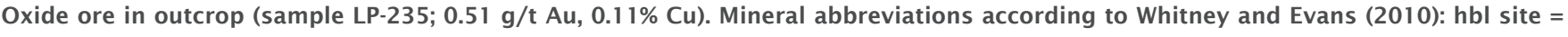
hornblende site, hem/gth = hematite/goethite, eng = enargite, $p y=$ pyrite.

idiomophic (hornblende and feldspar shape) to irregular, and their abundance generally reflects the presence of hornblende and feldspar phenocrysts in the volcanic host rock. The advanced argillic alteration zone is characterized by quartz, alunite supergroup minerals (e.g., alunite, natroalunite, aluminum phosphate-sulfate minerals), dickite, pyrophyllite, barite, illite, and minor diaspore and rutile. Argillic alteration produced quartz, kaolinite, illite, illite-smectite, and minor chlorite with local disseminated pyrite. The propylitic alteration zone contains chlorite, epidote, calcite, rutile, pyrite, chalcopyrite, and minor hematite and mag- netite. Stable isotope $(\mathrm{S}, \mathrm{O}, \mathrm{H})$ geochemistry and fluid inclusion studies revealed that hydrothermal alteration at Cerro Quema was produced by magmatic-hydrothermal fluids that were variably mixed with meteoric fluids (Corral et al., 2017).

\subsubsection{MINERALIZATION}

Mineralization at Cerro Quema can be subdivided into two different zones: (A) hypogene mineralization, produced by magmatic-hydrothermal fluids; and (B) supergene mineralization, produced by oxidation of the hypogene mineralization as well as by the precipitation of secondary sulfides. 
The different mineralization types and their distribution are fully described in Corral et al. (2016, 2017), and can be summarized as follows.

\section{HYPOGENE MINERALIZATION}

Hypogene mineralization is generally developed below the oxidized zone, but due to the rough and steep topography, small (meter scale) outcrops are locally found at the surface. Pyrite is the most abundant sulfide, although there is a diverse group of accompanying sulfides (e.g., enargite, tennantite, chalcopyrite, sphalerite, and bornite) also associated with the $\mathrm{Au}-\mathrm{Cu}$ mineralization.

Based on field and petrographic observations, hypogene mineralization has been divided into five stages, where stages 3 and 4 contain the majority of the metals. Stage 1 consists of disseminated, fine-grained, idiomorphic and subidiomorphic pyrite, accompanied by rutile and barite in vugs and disseminations, with minor enargite, tennantite, and chalcopyrite at depth (figures 2B, 4A, 4G). Sphalerite occurs as a trace mineral disseminated in the groundmass. Stage 2 is composed of disseminated pyrite in the cement of a hydraulic breccia, associated with alunite-natroalunite, dickite, and traces of chalcopyrite. Stage 3 consists of veinlets of pyrite, chalcopyrite, enargite, and tennantite that crosscut stages 1 and 2. Textures observed in Stage 3 veinlets show that pyrite is replaced by enargite, enargite is replaced by tennantite, and finally tennantite is replaced by chalcopyrite. Bornite occurs as a trace mineral. Stage 4 occurs as $\sim 5$ $\mathrm{cm}$ thick breccia bands, composed of pyrite, chalcopyrite, and minor enargite. The Stage 4 breccia bands crosscut all the previous stages. Stage 5 consists of 5 to $10 \mathrm{~cm}$ thick base metal sulfide-rich veins composed of pyrite, quartz, and barite together with minor chalcopyrite, sphalerite, and galena. Gold occurs as submicroscopic grains and as invisible gold within pyrite. Copper is associated with Cu-bearing sulfides and sulfosalts such as chalcopyrite, enargite, bornite, and tennantite.

\section{SUPERGENE MINERALIZATION}

Intense weathering has affected fresh and hydrothermally altered rocks in the Cerro Quema area down to depths of $150 \mathrm{~m}$ (Figure 2A). Weathering of the high-sulfidation ore has developed a thick quartz- and iron oxide-rich zone that overprints the primary sulfide-bearing zone. Quartz is relict of the hypogene hydrothermal alteration zone, and was not directly produced by the weathering or oxidation processes. This oxidized zone is developed in the upper part of the orebodies. It is characterized by vuggy quartz containing abundant hematite and goethite within the groundmass. The hematite and goethite replace the cement of hydrothermal breccias, and fill the vugs. Hypogene pyrite, barite, and rutile remain as trace minerals in the oxidation zone. Gold has been found as submicroscopic grains $(<1 \mu \mathrm{m})$, which prevented quantitative analysis of its chemical composition. Below the oxidation zone, supergene enrichment has caused deposition of secondary Cu-bearing minerals such as chalcocite and minor covellite. The secondary $\mathrm{Cu}$ sulfides are found replacing chalcopyrite, tennantite, and enargite as well as filling small fractures.

\subsubsection{AGE OF THE CERRO QUEMA DEPOSIT}

The age of Cerro Quema has been constrained from crosscutting relationships between the volcanic host rocks combined with biostratigraphic and Ar-Ar geochronological data. Ore formation is estimated to be Eocene ( 55-49 Ma) in age and it is interpreted to be related to subvolcanic porphyry intrusions contemporaneous with the Valle Rico batholith (Corral et al., 2016).

\section{Results of the Cerro Quema metal content}

\subsection{SAMPLING AND ANALYTICAL METHODS}

To study the geochemical compositions of the different Au-Cu ores at Cerro Quema, the samples have been subdivided into two groups according to their origin and metallurgical properties:

1) Sulfide ore: Samples dominantly showing hypogene mineralization and secondary enrichment but unaffected by oxidation (Figure 2B). 
Table 1. Summary of the analyzed samples, location, hydrothermal alteration, and trace element content. Abbreviations: AA = Argillic Alteration, AAA = Advanced Argillic Alteration, $\mathrm{VQ}=$ Vuggy Quartz Alteration, bdl = below detection limit.

\begin{tabular}{|c|c|c|c|c|c|c|c|}
\hline . & & 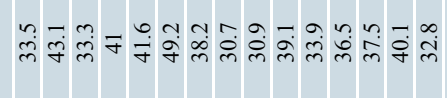 & ๗नुं & 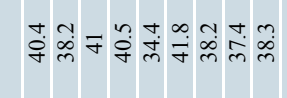 & צี & 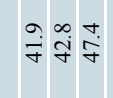 & \\
\hline & $\geqslant$ & 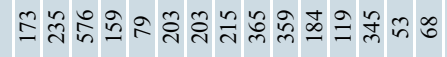 & ఫुऽ ळ స్ స్ & 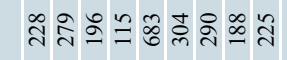 & 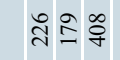 & 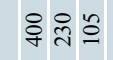 & है \\
\hline & क & 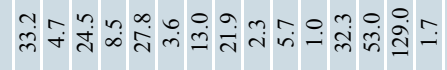 & 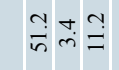 & 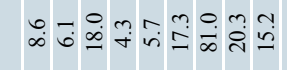 & iि & 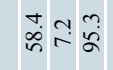 & \\
\hline & $\stackrel{00}{ \pm}$ & 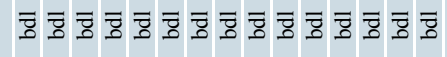 & $\bar{z} \bar{z} \bar{g}$ & 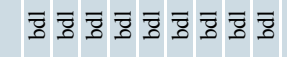 & $\bar{z}=\bar{z}$ & $\overline{\neq} \odot \bar{g}$ & ह \\
\hline & 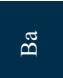 & 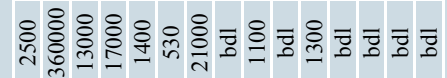 & 융큐 & ఫ్రి & $\bar{z} \bar{z}$ & 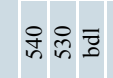 & \\
\hline & y & 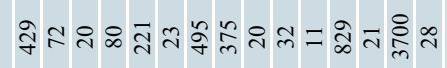 & $\stackrel{6}{0} \simeq \stackrel{8}{\square}$ & $\stackrel{\infty}{\infty}$ ๙ & 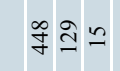 & 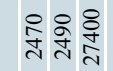 & \\
\hline & $\underset{d}{\stackrel{d}{e}}$ & 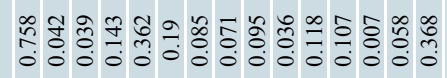 & 高导 & 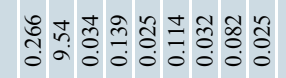 & 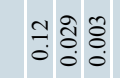 & $\begin{array}{ll}F \\
\text { Faำ } \\
0\end{array}$ & \\
\hline & กี & $m-\bar{z}+m m \sim m \sim \bar{\Xi}-N \bar{z} m \infty$ & $\mathrm{Z}^{8} \mathrm{~N} \pm m$ & $\Xi= \pm \sim r \sim n-n \bar{g}$ & $\Xi+\bar{\xi}$ & $\Xi^{ \pm}+\frac{d}{2}$ & \\
\hline & $\stackrel{2}{2}$ & 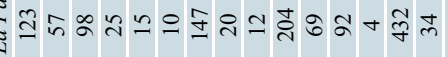 & 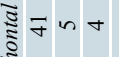 & 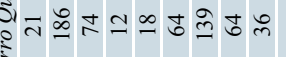 & $\stackrel{5}{2}$ & $\frac{2}{2}=6$ & \\
\hline & z & $+\bar{\Xi} \bar{\Xi}_{0} \sigma n+n--N+\bar{\Xi} m-$ & $v=\bar{z}$ & ง & $m-\bar{z}$ & $m-=$ & \\
\hline & $\stackrel{\circ}{\Sigma}$ & 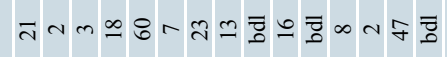 & $\stackrel{m}{\approx}$ in & ते $\bar{g}+\bar{z} n+ニ \bar{z}$ & $\bar{z} m \bar{\Xi}$ & $\alpha+ \pm$ & E \\
\hline & $\sum$ & 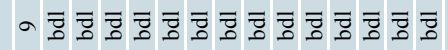 & $\bar{z} \curvearrowleft \bar{\Xi}$ & 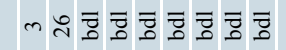 & $\bar{z} \bar{z} \bar{z}$ & 요 & \\
\hline & $z$ & స్రిలం & ฟูતે & 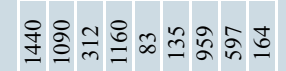 & हี่ & 융 & \\
\hline & $\Xi$ & 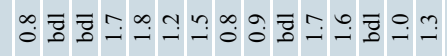 & $\stackrel{\infty}{\circ}=\bar{\Xi}$ & ษั & $\stackrel{\circ}{-}=\bar{\Xi}$ & 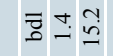 & \\
\hline & 妿 & 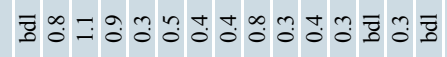 & 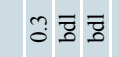 & :0 & $\because 3$ & $\stackrel{-9}{9}=$ & 효 \\
\hline & ₹ के & 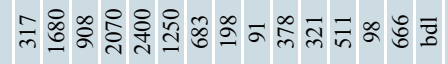 & $\bar{m} \bar{\Xi}$ & 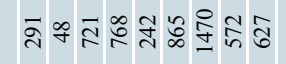 & 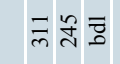 & 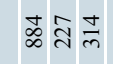 & mे \\
\hline & & 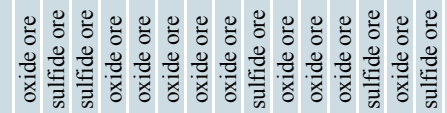 & 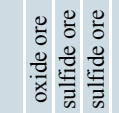 & 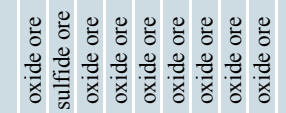 & 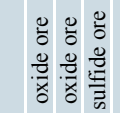 & 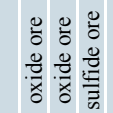 & \\
\hline & & 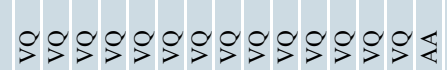 & 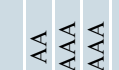 & 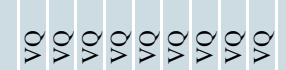 & 999 & 999 & 0 \\
\hline & & 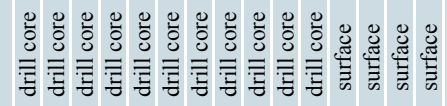 & 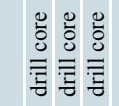 & 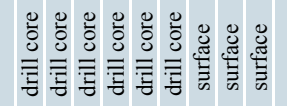 & 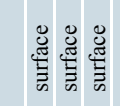 & 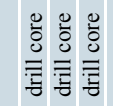 & \\
\hline 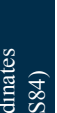 & 总 & 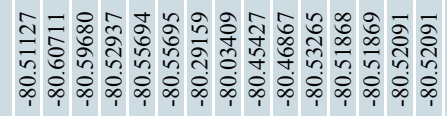 & 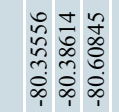 & 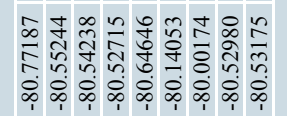 & 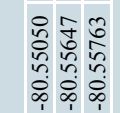 & 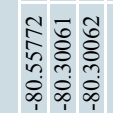 & \\
\hline 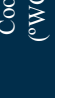 & 善 & 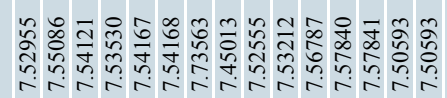 & 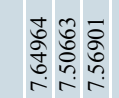 & 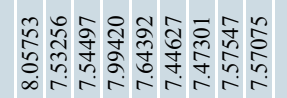 & 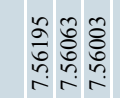 & 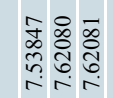 & \\
\hline & & 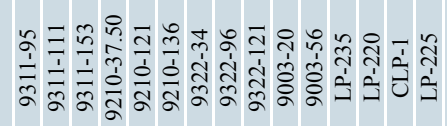 & 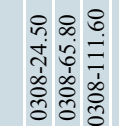 & 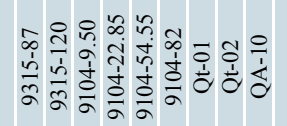 & 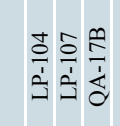 & 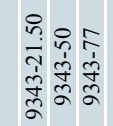 & \\
\hline
\end{tabular}


Table 2. Average enrichment factors for the oxide and sulfide ores with respect to the country rocks from Corral et al., (2011), and average enrichment factors of the oxide zone with respect to the sulfide zone. Element concentrations are expressed in ppm except for Au which is expressed in ppb.

\begin{tabular}{|l|c|c|c|c|c|c|c|}
\hline & $\mathrm{Au}$ & $\mathrm{Cu}$ & $\mathrm{Ag}$ & $\mathrm{Pb}$ & $\mathrm{Ni}$ & $\mathrm{Zn}$ & $\mathrm{S}$ \\
\hline Country rock average $(\mathrm{n}=6)$ & 7.93 & 125.43 & - & - & 16.00 & 68.43 & 0.01 \\
\hline Sulfide Ore enrichment $(\mathrm{n}=11)$ & 36.55 & 9.59 & - & - & 0.46 & 0.75 & 582.06 \\
\hline Oxide Ore enrichment $(\mathrm{n}=23)$ & 88.00 & 5.88 & - & - & 0.17 & 0.08 & 26.10 \\
\hline Oxide/Sulfide Ore enrichment & 2.41 & 0.61 & 1.24 & 1.86 & 0.37 & 0.11 & 0.04
\end{tabular}

2) Oxide ore: Samples with hypogene mineralization strongly affected by weathering and oxidation (Figure 2C, 2D).

A total of 34 representative samples of the sulfide ore $(\mathrm{n}=11)$ and of the oxide ore $(\mathrm{n}=23)$ were collected in different mineralized zones of Cerro Quema. Most samples belong to the vuggy quartz alteration zones; however, some samples from the advanced argillic $(\mathrm{n}=2)$ and argillic $(\mathrm{n}=1$; Table 1) alteration zones are also included. Whole rock geochemical analyses of $\mathrm{Au}, \mathrm{Ag}, \mathrm{Cd}, \mathrm{Cu}, \mathrm{Mn}$, $\mathrm{Mo}, \mathrm{Ni}, \mathrm{Pb}, \mathrm{Zn}, \mathrm{S}, \mathrm{As}, \mathrm{Ba}, \mathrm{Hg}$, Sb, and W concentrations were performed by INAA and with an aqua regia digestion followed by ICP-MS analysis on $30 \mathrm{~g}$ sample spits at Activation Laboratories, Canada [Code 1 EPI $(\mathrm{Au}+14)]$. Certain elements such as $\mathrm{Mn}$ and $\mathrm{Hg}$ mostly show concentrations below the analytical detection limit and therefore we have not considered them in the statistical calculations. Sample 9349-77 has a Cu content above the upper limit of detection (10000 ppm), therefore this value has been used as the minimum $\mathrm{Cu}$ content of the sample. Additionally, as samples were reduced to powder using a tungsten carbide mill, W concentrations should be regarded only as semi-quantitative due to possible contamination caused by the sample preparation method. The complete dataset of the analyzed rock, including the ore group and hydrothermal alteration zone, is presented in Table 1.

\subsection{WHOLE-ROGK DATA}

The results show that the oxide ore has the highest concentrations of $\mathrm{Au}(2.4 \mathrm{~g} / \mathrm{t}), \mathrm{Ag}(2.0 \mathrm{~g} / \mathrm{t}), \mathrm{Pb}$ (432 ppm), and $\mathrm{Sb}$ (317 ppm), whereas the sulfide ore has the highest concentrations of $\mathrm{Cu}(>1 \%)$, Zn (403 ppm), As (2.74\%), Cd (15.2 ppm), and S $(10.12 \%)$.

The average concentrations of elements in the oxide and sulfide ores divided by their average concentrations in the genetically related country rocks (i.e., diorites and quartz diorites; Corral et al., 2011) has been used as an indicator of the deposit enrichment factor (Table 2). Certain elements such as $\mathrm{Ag}, \mathrm{Cd}, \mathrm{Pb}, \mathrm{As}$, and $\mathrm{Hg}$ show concentrations below the detection limits in the country rocks, and therefore they have not been considered for the enrichment factor calculations. The enrichment factor of the oxide/sulfide ore was calculated by dividing the average concentration of elements in the oxide ore with their average concentration in the sulfide ore (Table 2).

The enrichment factors of mineralized rocks with respect to the country rock are up to 88 for $\mathrm{Au}$ and up to 9.59 for $\mathrm{Cu}$. Although $\mathrm{Au}$ and $\mathrm{Cu}$ are the elements of economic interest in the Cerro Quema deposit, the highest enrichment factor with respect to the country rock is shown by $\mathrm{Sb}(219)$, $\mathrm{Ba}$ (97), and S (582). Other elements such as Zn $(0.08)$ and $\mathrm{Ni}(0.17)$ are depleted with respect to the country rocks. The enrichment factors of the oxide ore with respect to the sulfide ore show that $\mathrm{Au}$ (2.41), Sb (2.11), $\mathrm{Pb}$ (1.86), and Ag (1.24) are primarily concentrated in the oxide zone, whereas $\mathrm{Cu}$ (0.61), Ni (0.37), As (0.30), Zn (0.11), Ba (0.10), and $\mathrm{S}(0.04)$ are primarily concentrated in the sulfide zone.

Correlation coefficients (Table 3) between element pairs were used to define element affinities and their mineral correlation. Due to the skewed population shown by the element concentrations, 
Table 3. Correlation coefficients ( $r$ ) of trace and major elements at Cerro Quema. Correlations were calculated for elements transformed to $\log$ values. Superindex indicates: $\mathrm{a}=$ strongly correlated, $\mathrm{b}=$ well correlated, $\mathrm{c}=$ poorly correlated.

\begin{tabular}{|c|c|c|c|c|c|c|c|c|c|c|c|c|}
\hline & $\mathrm{Au}$ & $\mathrm{Ag}$ & $\mathrm{Cd}$ & $\mathrm{Cu}$ & Mo & $\mathrm{Ni}$ & $\mathrm{Pb}$ & $\mathrm{Zn}$ & S & As & $\mathrm{Ba}$ & $\mathrm{Sb}$ \\
\hline \multicolumn{13}{|c|}{ Oxide Ore } \\
\hline $\mathrm{Au}$ & 1.00 & 0.31 & 0.14 & 0.36 & -0.04 & 0.37 & -0.02 & 0.10 & 0.1 & 0.00 & 0.07 & -0.08 \\
\hline $\mathrm{Ag}$ & & 1.00 & -0.34 & -0.31 & $0.43^{c}$ & -0.25 & -0.32 & 0.09 & -0.42 & -0.11 & 0.06 & -0.22 \\
\hline $\mathrm{Cd}$ & & & 1.00 & $0.57^{\mathrm{c}}$ & 0.27 & $0.58^{c}$ & -0.30 & 0.01 & 0.33 & -0.05 & 0.22 & -0.10 \\
\hline $\mathrm{Cu}$ & & & & 1.00 & 0.16 & $0.83^{b}$ & -0.01 & $0.53^{c}$ & $0.71^{\mathrm{b}}$ & 0.32 & 0.30 & 0.10 \\
\hline Mo & & & & & 1.00 & 0.24 & -0.35 & 0.25 & 0.06 & -0.24 & 0.28 & $-0.42^{c}$ \\
\hline $\mathrm{Ni}$ & & & & & & 1.00 & -0.02 & -0.14 & $0.48^{\mathrm{c}}$ & 0.18 & 0.34 & 0.13 \\
\hline $\mathrm{Pb}$ & & & & & & & 1.00 & 0.31 & -0.21 & 0.37 & -0.13 & 0.35 \\
\hline $\mathrm{Zn}$ & & & & & & & & 1.00 & $0.62^{b}$ & 0.38 & 0.20 & 0.05 \\
\hline $\mathrm{S}$ & & & & & & & & & 1.00 & 0.05 & $0.46^{\mathrm{c}}$ & -0.16 \\
\hline As & & & & & & & & & & 1.00 & -0.07 & $0.60^{\mathrm{b}}$ \\
\hline $\mathrm{Ba}$ & & & & & & & & & & & 1.00 & -0.32 \\
\hline $\mathrm{Sb}$ & & & & & & & & & & & & 1.00 \\
\hline
\end{tabular}

\begin{tabular}{|c|c|c|c|c|c|c|c|c|c|c|c|c|c|}
\hline & $\mathrm{Au}$ & $\mathrm{Ag}$ & $\mathrm{Cd}$ & $\mathrm{Cu}$ & $\mathrm{Mo}$ & $\mathrm{Ni}$ & $\mathrm{Pb}$ & $\mathrm{Zn}$ & $\mathrm{S}$ & $\mathrm{As}$ & $\mathrm{Ba}$ & $\mathrm{Sb}$ \\
\hline \begin{tabular}{|l|l|l|l|l|l|l|l|l|l|}
\hline Sulfide Ore \\
\hline $\mathrm{Au}$
\end{tabular} & 1.00 & $0.82^{\mathrm{b}}$ & 0.05 & 0.06 & -0.33 & -0.07 & $0.62^{\mathrm{b}}$ & -0.05 & -0.12 & 0.32 & $0.65^{\mathrm{b}}$ & $0.40^{\mathrm{c}}$ \\
\hline $\mathrm{Ag}$ & & 1.00 & 0.29 & 0.23 & $-0.48^{\mathrm{c}}$ & -0.02 & $0.68^{\mathrm{b}}$ & 0.07 & 0.00 & $0.40^{\mathrm{c}}$ & $0.58^{\mathrm{c}}$ & 0.31 \\
\hline $\mathrm{Cd}$ & & & 1.00 & $0.79^{\mathrm{b}}$ & -0.23 & $0.74^{\mathrm{b}}$ & $0.43^{\mathrm{c}}$ & $0.89^{\mathrm{b}}$ & $0.72^{\mathrm{b}}$ & $0.74^{\mathrm{b}}$ & $-0.43^{\mathrm{c}}$ & 0.16 \\
\hline $\mathrm{Cu}$ & & & & 1.00 & 0.05 & $0.77^{\mathrm{b}}$ & $0.40^{\mathrm{c}}$ & $0.90^{\mathrm{a}}$ & $0.90^{\mathrm{a}}$ & $0.71^{\mathrm{b}}$ & -0.12 & 0.00 \\
\hline $\mathrm{Mo}$ & & & & & 1.00 & -0.17 & $-0.67^{\mathrm{b}}$ & -0.09 & -0.10 & 0.13 & 0.30 & 0.32 \\
\hline $\mathrm{Ni}$ & & & & & & 1.00 & 0.30 & $0.41^{\mathrm{c}}$ & $0.89^{\mathrm{a}}$ & $0.46^{\mathrm{c}}$ & -0.36 & -0.08 \\
\hline $\mathrm{Pb}$ & & & & & & & 1.00 & $0.90^{\mathrm{a}}$ & $0.40^{\mathrm{c}}$ & 0.38 & $0.43^{\mathrm{c}}$ & 0.08 \\
\hline $\mathrm{Zn}$ & & & & & & & & 1.00 & $0.92^{\mathrm{a}}$ & $0.71^{\mathrm{b}}$ & -0.35 & 0.01 \\
\hline $\mathrm{S}$ & & & & & & & & & 1.00 & $0.51^{\mathrm{c}}$ & -0.21 & 0.15 \\
\hline $\mathrm{As}$ & & & & & & & & & & 1.00 & -0.11 & $0.52^{\mathrm{c}}$ \\
\hline $\mathrm{Ba}$ & & & & & & & & & & & 1.00 & -0.14 \\
\hline $\mathrm{Sb}$ & & & & & & & & & & & & 1.00 \\
\hline
\end{tabular}

calculations for element correlation were performed after previous transformation to log values as suggested by Kesler et al. (2003). In this study, correlation coefficient ranges have been defined as strongly correlated $(\mathrm{r}>0.90)$, well correlated $(0.60<\mathrm{r}<0.89)$, and poorly correlated $(0.40<\mathrm{r}$ $<0.59)$.
As shown in Table 3, the most significant correlations in the oxide ore are as follows: As is well correlated with $\mathrm{Sb} ; \mathrm{S}$ is well correlated with $\mathrm{Cu}$ and $\mathrm{Zn}$ and poorly correlated with $\mathrm{Ba}$. On the other hand, the most significant correlations in the sulfide ore are as follows: $\mathrm{Au}$ is well correlated with $\mathrm{Ag}, \mathrm{Pb}$, and $\mathrm{Ba}$, and poorly correlated with $\mathrm{Sb}$; 

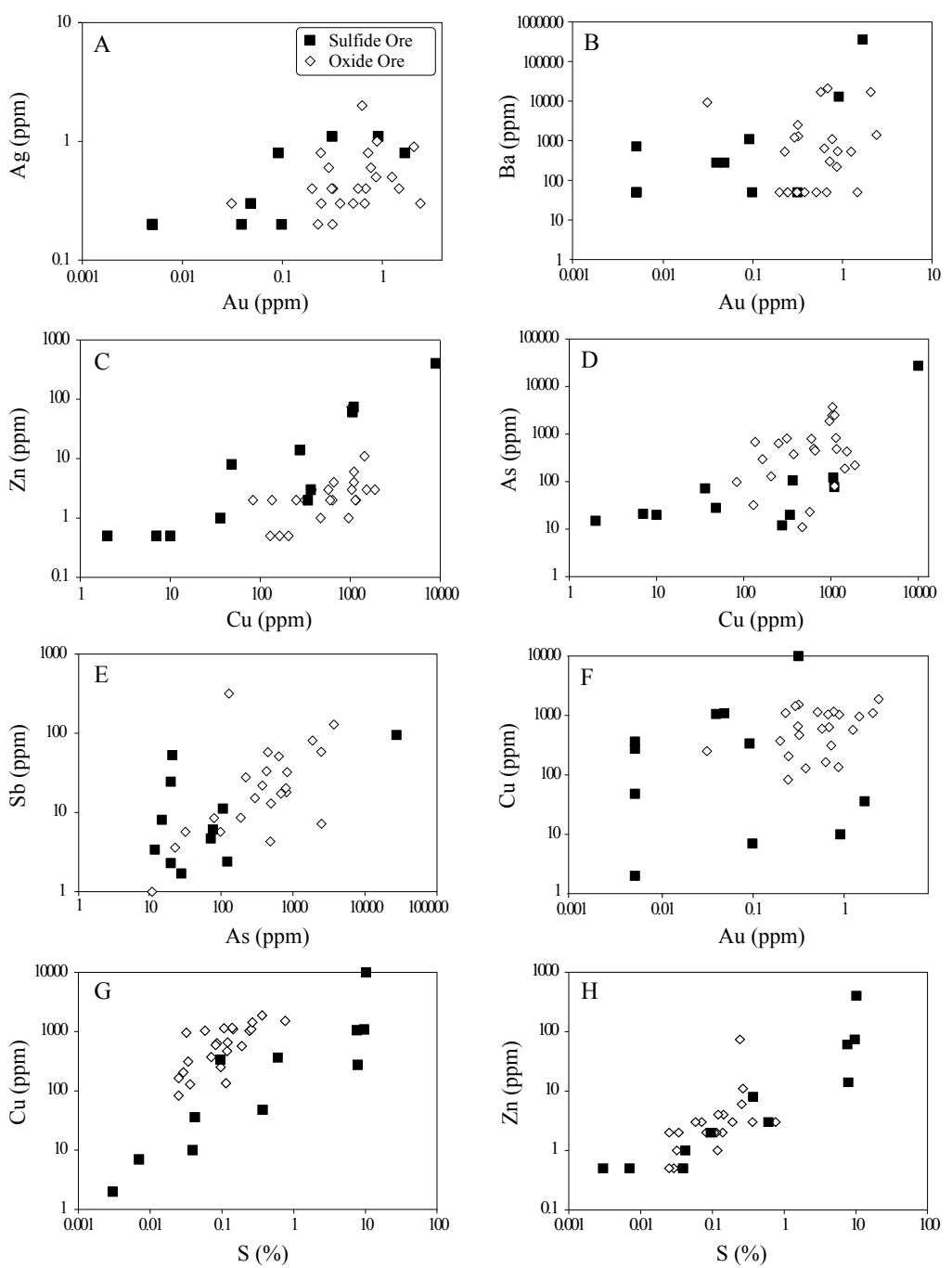

Figure 3 Correlation plots between element pairs. (A) Au-Ag. (B) Au-Ba. (C) Cu-Zn. (D) Cu-As. (E) As-Sb. (F) Au-Cu. (G) S-Cu. (H) S-Zn. Symbols for all graphs: squares = sulfide ore; diamonds = oxide ore.

$\mathrm{Ag}$ is well correlated with $\mathrm{Pb}$ and poorly correlated with As and $\mathrm{Ba} ; \mathrm{Cu}$ is strongly correlated with Zn, well correlated with Cd and As, and poorly correlated with $\mathrm{Pb}$; finally, $\mathrm{S}$ is strongly correlated with $\mathrm{Cu}, \mathrm{Ni}$, and $\mathrm{Zn}$.

\section{Discussion on the trace element distribution}

According to Corral et al. (2016, 2017), field, petrologic, and isotopic observations point towards a magmatic-hydrothermal fluid as the precursor of the mineralization and hydrothermal alteration. Later processes such as weathering and oxidation affected the hypogene minerals, leading to the development of the oxide ore.

In the sulfide ore, $\mathrm{Au}$ is well correlated with $\mathrm{Ag}, \mathrm{Pb}$, and $\mathrm{Ba}$ (Table 3; Figure 3A, 3B). Assuming that $\mathrm{Au}$ is present as invisible gold associated with the pyrite lattice (Corral et al., 201 1, 2016), the Au-Ba positive correlation (0.65) suggests that Au-bearing pyrite is associated with the presence of barite (Figure 4A, 4B). The high Ba enrichment in the sulfide zone with respect to the country rocks (97 times; Table 2) indicates that $\mathrm{Ba}$ was introduced 
by the hydrothermal fluid. Minor amounts of Ba could have also been liberated from feldspars during advanced argillic alteration processes. This contrasts with the Pueblo Viejo deposit (Kesler et al., 2003) where $\mathrm{Au}$ and $\mathrm{Ba}$ are not well correlated (0.12).

$\mathrm{Au}$ and $\mathrm{Ag}$ are also well and positively correlated (Figure 3A) suggesting the presence of both elements within the pyrite lattice. As the Ag content in the whole rock is up to $1.1 \mathrm{ppm}$ (sample 9311-153), and up to $400 \mathrm{ppm}$ in pyrite (Corral et al., 2016), the Ag content in the mineralized rock seems to be related to the presence of disseminated pyrite. Correlation of $\mathrm{Au}$ with $\mathrm{Pb}$ is not fully understood; however, $\mathrm{Pb}$ could be related to the presence of hokutolite (Pb-bearing barite), which usually occurs in hot spring environments (Hokuto and Peito hot spring, Taiwan and Tamagawa hot spring, Japan; Okamoto, 191 1; Sasaki and Minato, 1982; Momoshima et al., 1997) and in high-sulfidation deposits (Mt. Carlton, Australia; Sahlström et al., 2017). As previously mentioned, is related to high gold grades. $\mathrm{Cu}$ is strongly correlated with Zn, well correlated with $\mathrm{Cd}$ and As, and poorly correlated with $\mathrm{Pb}$ (Table 3; Figure 3C, 3D), suggesting that $\mathrm{Cu}$ may be associated with cupriferous pyrite (up to $3.67 \mathrm{wt} \% \mathrm{Cu}$ and up to $311 \mathrm{ppm} \mathrm{Cd}$; Corral et al., 2016) and also likely with chalcopyrite containing sphalerite inclusions. The good and positive correlation between $\mathrm{Cu}$ and $\mathrm{As}$ is explained by the presence of enargite (figures 3D, 4C) and other Cu-bearing sulfosalts (e.g., tennantite), which could also explain the correlation of $\mathrm{Cu}$ and As with $\mathrm{Zn}$ and $\mathrm{Ag}$ and of Sb with As (Figure 3E). The lack of strong correlation between $\mathrm{Cu}$ and $\mathrm{Au}$ (Figure 3F) may be due to the presence of these elements in different minerals such as $\mathrm{Au}$ occurring within the pyrite lattice, whereas $\mathrm{Cu}$ is associated with $\mathrm{Cu}$-bearing minerals (e.g., chalcopyrite, enargite and tennantite; Figure 4C, 4D). The strong correlations of $\mathrm{Zn}$ with $\mathrm{Cu}, \mathrm{Pb}$, and $\mathrm{S}$, and $\mathrm{Cu}$ with $\mathrm{S}$ (Figure $3 \mathrm{G}, 3 \mathrm{H}$ ), are caused by the presence of disseminated sphalerite and/or as sphalerite inclusions in pyrite/chalcopyrite, which could also explain the good correlation of $\mathrm{Zn}$ with Gd and As.

The element distribution and correlations observed in the oxide ore strongly differ from those in the sulfide ore. Weathering and oxidation of the sulfide ore produced dissolution of cupriferous pyrite, chalcopyrite, enargite, and tennantite, resulting in the concentration of $\mathrm{Au}, \mathrm{Ag}, \mathrm{Pb}$, and $\mathrm{Sb}$ (likely immobile elements), and in the bleaching of $\mathrm{Cd}, \mathrm{Cu}, \mathrm{Zn}$, and As (likely more mobile elements). In the oxide zone, Au and Ag are not well correlated with each other nor with other trace elements (Table 3), which could be explained from the difference in element mobility during mineral dissolution/precipitation/remobilization (e.g., Andreu et al., 2015). Contrary to the sulfide ore, Au and $\mathrm{Ba}$ are not well correlated in the oxide ore $(0.65$ and 0.07 , respectively). However, they still show an overall positive slope in the correlation plots, indicating that the highest $\mathrm{Au}$ concentrations match with the highest $\mathrm{Ba}$ concentrations (Figure 3B). Barite has been described as associated with gold in other high-sulfidation epithermal deposits such as El Indio-Tambo (Chile; Siddeley and Araneda, 1990; Jannas et al., 1990, 1999), Summitville (Colorado; Steven and Ratté, 1960; Stoffregen, 1987), Chinkuashih (Taiwan; Huang, 1955, 1962), and Furtei (Sardina; Ruggieri, 1992, 1993; Ruggieri et al., 1997). Anomalous concentrations of Ba could, therefore, be a prospective guide to high-grade $\mathrm{Au}$ mineralization in high-sulfidation epithermal deposits.

As and $\mathrm{Sb}$ are strongly correlated (Figure $3 \mathrm{E}$ ) and do not correlate well with other trace elements, suggesting that As and $\mathrm{Sb}$ could be present as oxides/hydroxides in this ore. $\mathrm{Cu}$ is well correlated with $\mathrm{Ni}$ and $\mathrm{S}$ suggesting they are associated with relicts of disseminated pyrite of the sulfide ore (up to $3.67 \mathrm{wt} \% \mathrm{Cu}$ and $4300 \mathrm{ppm} \mathrm{Ni}$; Corral et al., 2016). S and $\mathrm{Zn}$ are well correlated, which is explained by the observed although scarce disseminated sphalerite. 

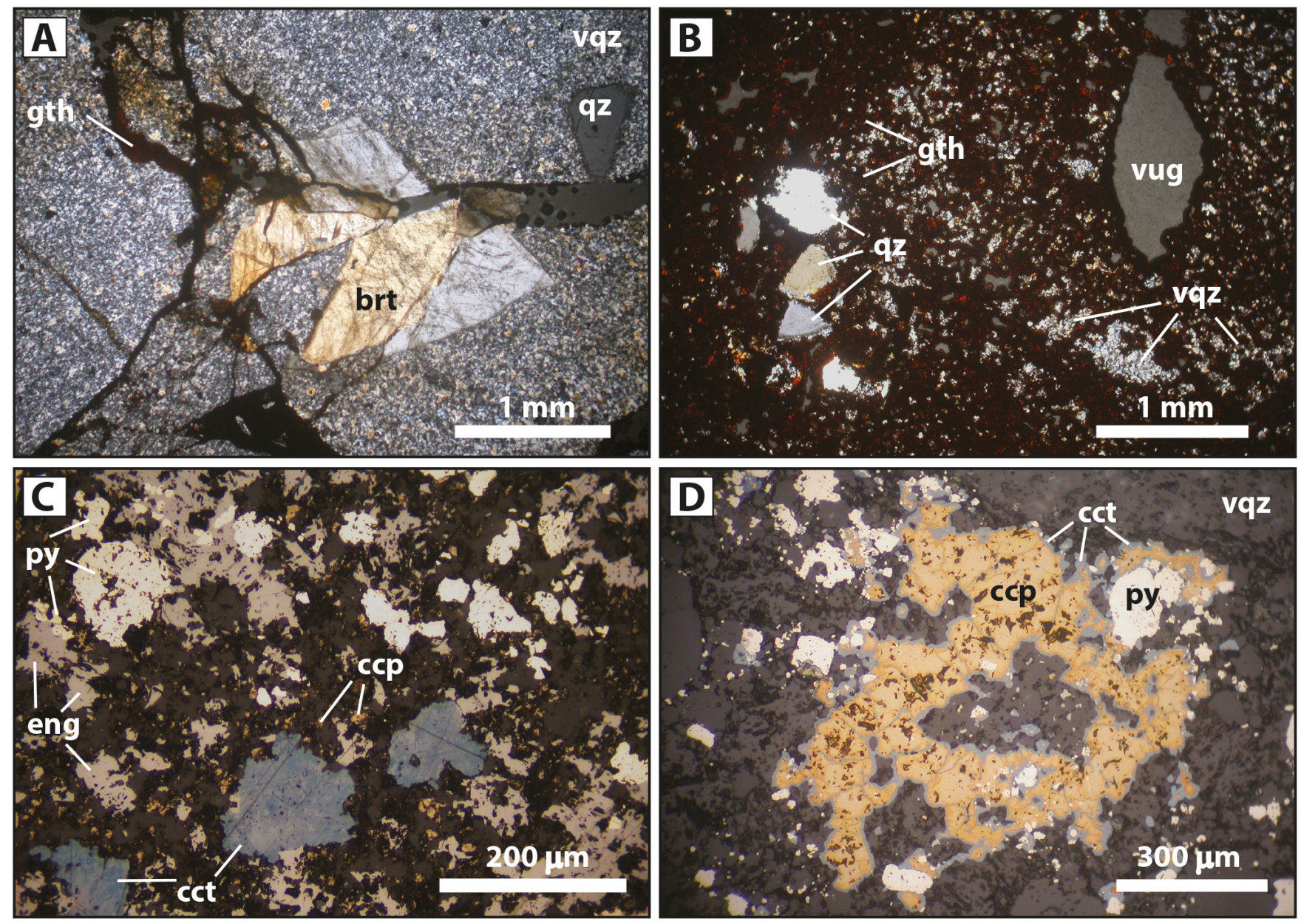

Figure 4 Microphotographs of Cerro Quema ores. (A) Oxide ore: oxidized vuggy quartz altered dacite with barite and elevated gold grade (sample 9322-34; $0.68 \mathrm{~g} / \mathrm{t} \mathrm{Au,} 21000$ ppm Ba; cross-polarized transmitted light). (B) Oxide ore: massively oxidized vuggy quartz altered dacite (sample 9210-121; $2.40 \mathrm{~g} / \mathrm{t} \mathrm{Au}, 1400 \mathrm{ppm}$ Ba; cross-polarized transmitted light). (C) Sulfide ore: detail of a sulfide microveinlet (Stage 3) constituted by pyrite, enargite, and minor chalcopyrite. Chalcocite replaces enargite. Host rock is a vuggy quartz altered dacite (sample 0308-11 1.60; $1.68 \mathrm{~g} / \mathrm{t}$ Au; reflected polarized light). (D) Sulfide ore: detail of a breccia band (Stage 4) constituted by pyrite and chalcopyrite. Chalcocite replaces chalcopyrite. Groundmass is a vuggy quartz altered dacite (reflected polarized light). Mineral abbreviations according to Whitney and Evans (2010): brt = barite, $\mathbf{c c p}=$ chalcopyrite, cct $=$ chalcocite, eng $=$ enargite, gth = goethite, py = pyrite, qz = quartz phenocryst, vqz = vuggy quartz alteration.

Only two analyzed samples have $\mathrm{Hg}$ contents above the detection limit (11 and $6 \mathrm{ppm})$. As $\mathrm{Hg}$ is commonly partitioned into a rising vapor phase by boiling (Barnes and Seward, 1997), the observed low concentrations of $\mathrm{Hg}$ may suggest that the present day exposure at Cerro Quema represents a relatively deeper portion of the hydrothermal system, and that the shallowest portion of the system has been eroded.

\section{Summary and implications for exploration}

Weathering and oxidation processes at the Cerro Quema deposit led to the development of two distinct ore zones. An upper iron oxide-rich zone (oxide ore), where $\mathrm{Au}, \mathrm{Ag}, \mathrm{Pb}$, and $\mathrm{Sb}$ are concen- 
trated, is characterized by goethite-hematite, free gold $(\mathrm{Au} \pm \mathrm{Ag})$, relicts of disseminated pyrite and sphalerite, and barite (associated with elevated Au grades). A lower sulfide-rich zone (sulfide ore), where $\mathrm{Cu}, \mathrm{Cd}, \mathrm{Zn}, \mathrm{Ni}$, and $\mathrm{As}$ are concentrated, is constituted by auriferous pyrite $( \pm \mathrm{Cu}-\mathrm{Ag})$, chalcopyrite ( \pm sphalerite inclusions), enargite-tennantite, secondary copper sulfides (e.g., chalcocite, covellite), and barite.

In terms of exploration, the most significant observation from the trace element distribution and correlation factors is that exploration for $\mathrm{Au}$ should target the oxide ore in areas showing high $\mathrm{Ba}$ anomalies. On the other hand, exploration for $\mathrm{Cu}$ should target the sulfide zone, below the oxidation boundary, where primary copper sulfides and sulfosalts (e.g., chalcopyrite, enargite, tennantite) and secondary copper sulfides (e.g., chalcocite, covellite) are present.

Statistical calculations carried out in this study show the potential of the correlation factors between different trace elements to target and distinguish different ore zones with different metallurgical properties. This methodology may be applicable to other deposits in similar geologic environments elsewhere.

\section{Acknowledgements}

This study is part of the first author's Ph.D., performed within the framework of the Ph.D. program in geology of the Universitat Autònoma de Barcelona. The research was supported by the research project CGL2007-62690/BTE (Spanish Ministry of Science and Education) and by a predoctoral grant from the Departament d'Universitats, Recerca i Societat de la Informació (Generalitat de Catalunya). The corresponding author would like to express his gratitude to the SEG Foundation and the SEG Canada Foundation for the Hugh E. McKinstry student research grants (2009, 2010, and 2011), which paid for part of the field and field-related laboratory research expenses. We thank Bellhaven Copper and Gold Inc. for access to mine samples and drill cores used in this study. We greatly appreciate the revision and comments of an earlier version of the manuscript by Prof. Esteve Cardellach as well as of the latest version revision by Mr. Fredrik Sahlström. We acknowledge Mr. Helge Behnsen for reviewing the English of the manuscript. This research work significantly benefited from a thorough review and many constructive comments by Dr. Lisard Torró, Dr. Marc Campeny, and Mr. Carl Nelson.

\section{References}

Andreu, E., Torró, L., Proenza, J.A., Domenech, C., García-Casco, A., Villanova de Benavent, C., Chavez, C., Espaillat, J., Lewis, J.F., 2015, Weathering profile of the Cerro de Maimón VMS deposit (Dominican Republic): textures, mineralogy, gossan evolution and mobility of gold and silver: Ore Geology Reviews, 65, 165-179.

Arribas, A.jr., 1995, Characteristics of highsulfidation epithermal deposits, and their relation to magmatic fluid, in Thompson, J.F.H. (ed.), Magmas, Fluids, and Ore Deposits: Victoria, Canada, Mineralogical Association of Canada Short Course, 23, 419-454.

Arribas, A.jr., Cunningham, C.G., Rytuba, J.J., Rye, R.O., Kelly, W.C., Podwysocki, M.H., McKee, E.H., Tosdal, R.M., 1995, Geology, geochronology, fluid inclusions, and isotope geochemistry of the Rodalquilar gold alunite deposit, Spain: Economic Geology, 90, 795-822.

Barnes, H.L., Seward, T.M., 1997, Geothermal systems and mercury deposits, in Barnes, H.L. (ed.), Geochemistry of hydrothermal ore deposits: New York, U.S.A., John Wiley \& Sons, 699-736. 
Baumgartner, R., Fontboté, L., Vennemann, T., 2008, Mineral Zoning and Geochemistry of Epithermal Polymetallic Zn-Pb-Ag-CuBi Mineralization at Cerro de Pasco, Peru: Economic Geology, 103, 493-537.

Buchs, D.M., Arculus, R.J., Baumgartner, P.O., Baumgartner-Mora, C., Ulianov, A., 2010, Late Cretaceous arc development on the SW margin of the Caribbean Plate: Insights from the Golfito, Costa Rica, and Azuero, Panama, complexes: Geochemistry, Geophysics, Geosystems, 11(7), Q07S24.

Buchs, D.M., Baumgartner, P.O., BaumgartnerMora, C., Flores, K., Bandini, A.N., 2011, Upper Cretaceous to Miocene tectonostratigraphy of the Azuero area (Panama) and the discontinuous accretion and subduction erosion along the Middle American margin: Tectonophysics, 512, 31-46.

Chang, Z., Hedenquist, J.W., White, N.C., Cooke, D.R., Roach, M., Deyell, C.L., Garcia, J.jr., Gemmell, J.B., McKnight, S., Guison, A.L., 2011, Exploration Tools for Linked Porphyry and Epithermal Deposits: Example from the Mankayan Intrusion-Centered $\mathrm{Cu}-\mathrm{Au}$ District, Luzon, Philippines: Economic Geology, 106(8), 1365-1398.

Corbett, G.J., Leach, T.M., 1998, Southwest Pacific Rim gold-copper systems; structure, alteration, and mineralization: Society of Economic Geologists Special Publication, 6, $236 \mathrm{p}$.

Corral, I., Griera, A., Gómez-Gras, D., Corbella, M., Cardellach, E., 2010, Geochemical evolution of the Panamanian CretaceousPaleogene volcanic arc: Insights from the Azuero Peninsula, SW Panama: Geogaceta, 49, 79-82.

Corral, I., Griera, A., Gómez-Gras, D., Corbella, M., Canals I Sabaté, À., Pineda-Falconett, M., Cardellach, E., 2011, Geology of the Cerro Quema Au-Cu deposit (Azuero
Peninsula, Panama): Geologica Acta, 9, 481-498.

Corral, I., Gómez-Gras, D., Griera, A., Corbella, M., Cardellach, E., 2013, Sedimentation and Volcanism in the panamanian Cretaceous intra-oceanic arc and fore-arc: New insights from the Azuero Peninsula (SW Panama): Bulletin de la Société Géologique de France, 184, 35-45.

Corral, I., Cardellach, E., Corbella, M., Canals, À., Gómez-Gras, D., Griera, A., Cosca, M.A., 2016, Cerro Quema (Azuero Peninsula, Panama): Geology, Alteration, Mineralization, and Geochronology of a Volcanic Dome-Hosted High-Sulfidation Au-Cu Deposit: Economic Geology, 111(2), 287-310.

Corral, I., Cardellach, E., Corbella, M., Canals, À., Griera, A., Gómez-Gras, D., Johnson, C. A., 2017, Origin and evolution of mineralizing fluids and exploration of the Cerro Quema $\mathrm{Au}-\mathrm{Cu}$ deposit (Azuero Peninsula, Panama) from a fluid inclusion and stable isotope perspective: Ore Geology Reviews, 80, 947-960.

Deditius, A.P., Utsunomiya, S., Ewing, R.C., Chryssoulis, S.L., Venter, D., Kesler, S.E., 2009, Decoupled geochemical behavior of As and $\mathrm{Cu}$ in hydrothermal systems: Geology, 37(8), 707-710.

Del Giudice, D., Recchi, G., 1969, Geologia del area del Proyecto Minero de Azuero, Informe técnico preparado para el gobierno de la Republica de Panama por las Naciones Unidas, actuando y participando como agencia ejecutora: Panamá, Gobierno de la República de Panamá, 48 p.

Ferenčić, A., 1970, Porphyry copper mineralization in Panama: Mineralium Deposita, 5(4), 383-389.

Ferenčić, A., 1971, Metallogenic provinces and epochs in southern Central America: Mineralium Deposita, 6(1), 77-88. 
Hedenquist, J.W., Matsuhisa, Y., Izawa, E., White, N.G., Giggenbach, W.F., Aoki, M., 1994, Geology, geochemistry, and origin of high sulfidation $\mathrm{Cu}-\mathrm{Au}$ mineralization in the Nansatsu District, Japan: Economic Geology, 89(1), 1-30.

Heinrich, C.A., Driesner, T., Stefánsson, A., Seward, T.M., 2004, Magmatic vapor contraction and the transport of gold from the porphyry environment to epithermal ore deposits: Geology, 32(9), 761-764.

Hernandez, P.A., Garcia-Estrada, P.A., Cowley, P.N., 1989, Geological setting, alteration and lithogeochemistry of the Transaccion epithermal gold deposit, Rodalquilar mining district, Southeast Spain: Transactions of the Institution of Mining and Metallurgy, Section B, Applied Earth Science, 98, 78-80.

Hoernle, K., Hauff, F., van den Bogaard, P., 2004, 70 m.y. history (139-69 Ma) for the Caribbean large igneous province: Geology, 32(8), 697-700.

Hoernle, K., van den Bogaard, P., Werner, R., Lissinna, B., Hauff, F., Alvarado, G., GarbeSchönberg, D., 2002, Missing history (16-71 $\mathrm{Ma}$ ) of the Galápagos hotspot: Implications for the tectonic and biological evolution of the Americas: Geology, 30(9), 795-798.

Horlacher, C.F., Lehmann, J.H., 1993, Regional Geology, Geochemistry and Exploration potential of the central Cerro Quema concession, Panama: Panama, Technical Report, 36 p.

Huang, C.K., 1955, Gold-copper deposits of the Chinkuashih mine, Taiwan, with special reference to the mineralogy: Acta Geologica Taiwanica, 7, 1-20.

Huang, G.K., 1962, Textures and structures of the Gold-Copper ores of the Chinkuashih mine, Taiwan: The Journal of the Japanese Association of Mineralogists, Petrologists and Economic Geologists, 47(6), 232-240.
Jannas, R.R., Beane, R.E., Ahler, B.A., Brosnahan, D.R., 1990, Gold and copper mineralization at the El Indio deposit, Chile: Journal of Geochemical Exploration, 36, 233-266.

Jannas, R.R., Bowers, T.S., Petersen, U., Beane, R.E., 1999, High-sulfidation deposit types in the El Indio district, Chile, in Skinner, B.J. (ed.), Geology and ore deposits of the Central Andes: Society of Economic Geologists Special Publication, 7, 219-266.

Kerr, A.C., Marriner, G.F., Tarney, J., Nivia, A., Saunders, A.D., Thirlwall, M.F., Sinton, C.W., 1997, Cretaceous basaltic terranes in western Colombia: Elemental, chronological and $\mathrm{Sr}-\mathrm{Nd}$ isotopic constraints on petrogenesis: Journal of Petrology, 38(6), 677-702.

Kesler, S.E., Sutter, J.F., Issigonis, M.J., Jones, L.M., Walker, R.L., 1977, Evolution of porphyry copper mineralization in an oceanic island arc; Panama: Economic Geology, 72(6), $1142-1153$

Kesler, S.E., Russell, N., McCurdy, K., 2003, Trace-metal content of the Pueblo Viejo precious-metal deposits and their relation to other high-sulfidation epithermal systems: Mineralium Deposita, 38(6), 668-682.

Kesler, S.E., Campbell, I.H., Smith, C.N., Hall, C.M., Allen, G.M., 2005, Age of the Pueblo Viejo Gold-Silver Deposit and Its Significance to Models for High-Sulfidation Epithermal Mineralization: Economic Geology, 100(2), 253-272.

Kolarsky, R.A., Mann, P., Monechi, S., 1995, Stratigraphic development of southwestern Panama as determined from integration of marine seismic data and onshore geology, in Mann, P. (ed.), Geologic and Tectonic Development of the Caribbean Plate Boundary in Southern Central America: Boulder, Colorado, U.S.A., Geological Society of America Special Paper, 295, 159-200. 
Kwan, K., Prikhodko, A., Legault, J.M., Plastow, G.C., Kapetas,J., Druecker, M., 2016, VTEM airborne EM, aeromagnetic and gamma-ray spectrometric data over the Cerro Quema high sulphidation epithermal gold deposits, Panama: Exploration Geophysics, 47(3), 179-190.

Leach, T.M., 1992, Petrological Evaluation of the High Sulphidation Systems in the La Pava and Cerro Quema Prospect Areas, Panama, for Cyprus Gold Company: Auckland, N.Z., CMS New Zealand Ltd., Report 473, 80 p.

Lissinna, B., 2005, A profile through the Central American Landbridge in western Panama: $115 \mathrm{Ma}$ Interplay between the Galápagos Hotspot and the Central American Subduction Zone: Kiel, Germany, ChristianAlbrechts Universität zu Kiel, PhD Thesis, $102 \mathrm{p}$.

Montes, C., Bayona, G.A., Cardona, A., Buchs, D.M., Silva, C.A., Morón, S.E., Hoyos, N., Ramírez, D.A., Jaramillo, C.A., Valencia, V., 2012, Arc-continent collision and orocline formation: Closing of the Central American seaway: Journal of Geophysical Research, 117, B04105.

Momoshima, N., Nita, J., Maeda, Y., Sugihara, S., Shinno, I., Matsuoka, N., Huang, C.W., 1997, Chemical composition and radioactivity in hokutolite (plumbian barite) collected at Peito hot spring, Taiwan: Journal of Environmental Radioactivity, 37(1), 85-99.

Nelson, G.E., 1995, Porphyry copper deposits of southern Central America: Arizona Geological Society Digest, 20, 553-565.

Okamoto, Y., 1911, On a Radioactive Mineral, found as Crust under the Hot Spring Water of Hokuto in Taiwan: The Journal of the Geological Society of Japan, 18, 19-26.

Ruggieri, G., 1992, Minerogenesi in ambiente epitermale:GliEsempiDelleMineralizzazioni Aurifere di Furtei (Sardegna), Frassine e
La Campigliola (Toscana Meridionale): Florence, Italy, Università di Firenze e Perugia, PhD Thesis, 154 p.

Ruggieri, G., 1993, Ore genesis in epithermal environment: the examples of Furtei (Sardinia), Frassine and La Campigliola (Southern Tuscany) gold mineralization: Plinius Supplemento italiano all'European Journal of Mineralogy, 9, 134-139.

Ruggieri, G., Lattanzi, P., Luxoro, S.S., Dessi, R., Benvenuti, M., Tanelli, G., 1997, Geology, mineralogy, and fluid inclusion data of the Furtei high-sulfidation gold deposit, Sardinia, Italy: Economic Geology, 92(1), 1-19.

Sahlström, F., Arribas, A., Dirks, P., Corral, I., Chang. Z., 2017, Mineralogical distribution of Germanium, Gallium and Indium at the Mt. Carlton High-Sulfidation epithermal deposit, NE Australia, and comparison with similar deposits worldwide: Minerals, 7, 213.

Sasaki, N., Minato, H., 1982, Relationship between lattice constants and strontium and calcium contents of hokutolite: Mineralogical Journal, 11(2), 62-71.

Siddeley, G., Areneda, R., 1990, Gold-silver occurrences of the El Indio belt, Chile, in Ericksen, G.E., Cañas-Pinochet, M.T., Reinemund, J.A. (eds.), Geology of the Andes and Its Relation to Hydrocarbon and Mineral Resources: Houston, U.S.A., Circum- Pacific Council for Energy and Mineral Resources, Earth Science Series, 11, 273-284.

Sutcliffe, R., Kuchling, K., Burga, D., Armstrong, T., Yassa, A., Brown, F., Puritch, E., Tortelli, G., Lightwood, G., Brown, D., Gorman, M., 2014, Cerro Quema Project-Pre-feasibility study on the La Pava and Quemita oxide gold deposits 10,000 tpd Heap Leach, Prepared for Pershimco Resources Inc:Reno, U.S.A., P\&E Mining Consultants Inc., Golder Associates Inc., Kappers, Cassiday and Associates, Technical Report, 280 p. 
Sillitoe, R.H., 1995, Exploration of porphyry copper lithocaps: Publications Australasian Institute of Mining and Metallurgy, 9, 527-532.

Sillitoe, R.H., Hall, D.J., Redwood, S.D., Waddell, A.H., 2006, Pueblo Viejo high-sulfidation epithermal gold-silver deposit, Dominican Republic: A new model of formation beneath barren limestone cover: Economic Geology, 101(7), 1427-1435.

Steven, T.A., Ratté, J.C., 1960, Relation of mineralization to caldera subsidence in the Creede District, San Juan Mountains, Colorado: Short papers in the Geological Sciences, U.S. Geological Survey, Professional paper 400B, 14-17.

Stoffregen, R.E., 1987, Genesis of acid-sulfate alteration and $\mathrm{Au}-\mathrm{Cu}-\mathrm{Ag}$ mineralization at Summitville, Colorado: Economic Geology, 82(6), 1575-1591.

Sutopo, B., 2013, The Martabe Au-Ag highsulfidation epithermal deposits, Sumatra, Indonesia: Implications for ore genesis and exploration: Tasmania, Australia, University of Tasmania, $\mathrm{PhD}$ Thesis, $332 \mathrm{p}$.

Torrey, C., Keenan, J., 1994, Cerro Quema Project, Panama, Prospecting in tropical and arid terrains: Toronto, Canada, Technical Report, 23 p.

Whitney, D.L., Evans, B.W., 2010, Abbreviations for names of rock-forming minerals: American Mineralogist, 95(1), 185-187.

Wegner, W., Wörner, G., Harmon, R.S., Jicha, B.R., 2011, Magmatic history and evolution of the Central American Land Bridge in Panama since Cretaceous times: Geological Society of America Bulletin, 123, 703-724.

Wörner, G., Harmon, R.S., Wegner, W., 2009, Geochemical evolution of igneous rocks and changing magma sources during the formation and closure of the Central American land bridge of Panama, in Kay, S.M., Ramos, V.A., Dickinson, W.R. (eds.), Backbone of the Americas: Shallow Subduction, Plateau Uplift, and Ridge and Terrane Collision: Geological Society of America Memoir, 204, 183-196.

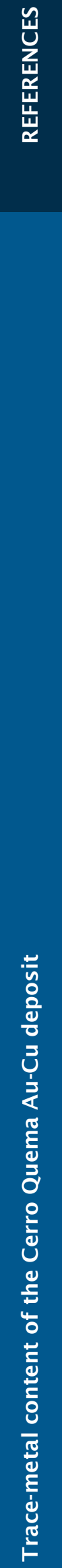

